\title{
Book Repair Workshops in North Carolina: This is How We Do it
}

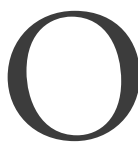
ften, as preservation or conservation professionals, we tend to fixate on the highend work of book conservation. This makes sense because this work is often amazing and wonderful to see. It is gratifying to know about the expert work being done by conservators across North Carolina. However, the most basic work in book conservation, the simple repairs, I believe, are just as important. These simple repairs: tipping-in a loose page, repairing a loose or broken hinge with Japanese tissue, using heat-set tissue to repair torn or damaged pages, replacing an end sheet and spine replacement are worthwhile for any library collection. Basic conservation work also is widely needed across libraries and archives; in North Carolina, basic book repair is the State Library of North Carolina's most requested training.

For approximately 20 years, I have taught a variety of book repair workshops across North Carolina. Primarily, these workshops have been conducted in public libraries from Asheville to Manteo, and many cities in between. This has been rewarding in so many ways, as the individuals who attend these workshops are thirsty for tips, clues, suppliers, and techniques. In many public libraries, there is no conservation person and repair work is often assigned to an employee who expresses an interest. Even then, local libraries have few resources or money for supplies to make these repairs. These small organizations with collections need basic knowledge but are often not able to obtain it. Enter the book repair workshop. Affordability is vital for smaller institutions. Knowing that they can both afford repair supplies and actually do the repairs opens the door to maintaining their collections. I must emphasize, just as I do in these workshops, that these repairs are for circulating materials, not Special Collections.

The basic workshop has been my most commonly taught and useful workshop and is offered once or twice a year. This workshop covers a variety of repairs, all of which can be learned easily. The State Library of North Carolina through the Department of
Natural and Cultural Resources sponsors these workshops and the response from the attendees has been very positive, based on post-workshop surveys. The North Carolina Preservation Consortium (ncpreservation.org) has also long supported workshops to teach library personnel how to make basic repairs to their collections. Yes, we live in the digital age, but collections contain a lot of print materials!

Let's start with some rules: do no harm and make your repair reversible. Every repair a person performs should be minimal and hopefully do nothing harmful to the item. Also, the use of acid-free materials is a necessity as this protects the item from future damage caused by acidic paper or adhesives. The materials you use in the repair cloth, paper and adhesives - should have neutral $\mathrm{pH}$.

Workshop tools include a bone folder made of bone or Teflon, a knife (like those made by Olfa or Xacto), a glue brush, scissors, a metal ruler, a micro-spatula, and at least one pencil. I also provide a piece of binder's board, also called Davey board, as a cutting

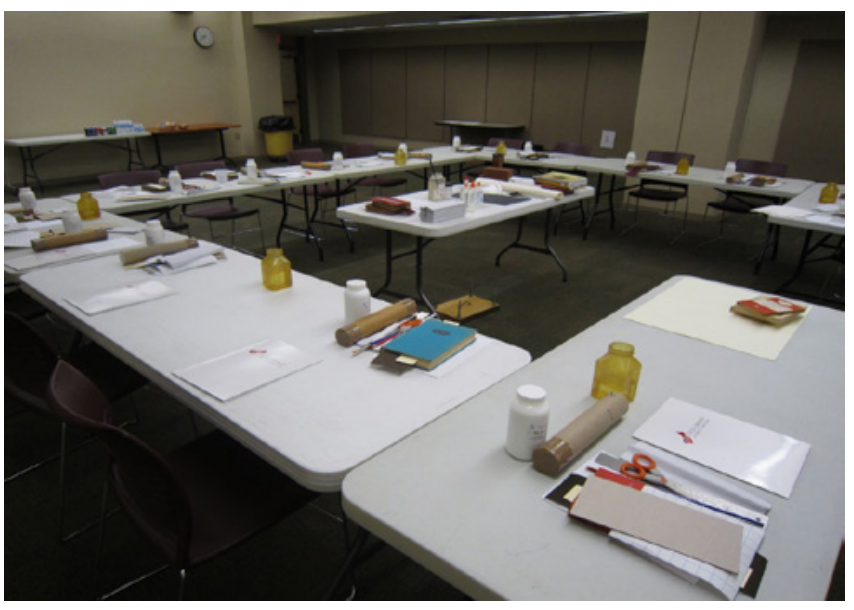

Book repair workshop set up at the Pack Library, Asheville, NC

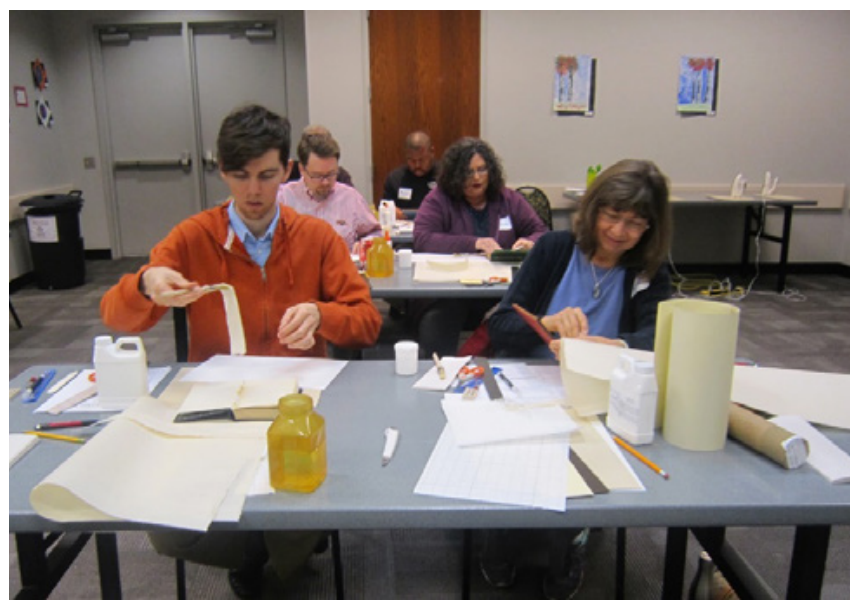

Workshop at Wake County Public Library, Raleigh, NC 
surface for the workshops, though long-term a cutting mat is best.

I begin the instruction process with a simple technique: tipping-in a loose page. This involves placing a thin bead of polyvinyl acetate adhesive (PVA) in the joint where a loose page once resided. PVA can be purchased in a variety of sizes from many library supply companies, such as University Products, Talas, or Gaylord Archival. PVA is a synthetic adhesive which is very flexible, has a $\mathrm{pH}$ neutral formulation, and dries quickly. For this technique, a Sally's Beauty Supply Color Applicator bottle or a Micromark Bellows Glue Applicator are great because they have a thin tip that applies only a small amount of PVA, which is all that is needed. PVA can be applied to the edge or edges of pages many ways. Once the page has PVA applied to it, and is inserted into the joint of the book, place a weight on top of the closed book. For weights, I normally use a brick covered with book cloth or felt: easy to find or make. However, almost anything heavy and not too bulky can become a weight: small containers filled with ball bearings, small and heavy pieces of clean metal, or baggies filled with sand, for example. After drying for an hour under a weight, the repaired book is ready.

After tipping-in loose pages, workshop attendees move to another simple technique: repairing a broken interior book hinge. Often, a crack develops between the cover and text block of a book, and repairing this break calls for more than a little PVA. I use Sekishu Japanese paper, a hand-made, medium weight paper made of kozo fiber, for this repair. The paper should be torn into strips, which you then glue and place centrally over the break. Once in place, use your fingers and a bone folder to press the strips into place and leave the book open to dry. This

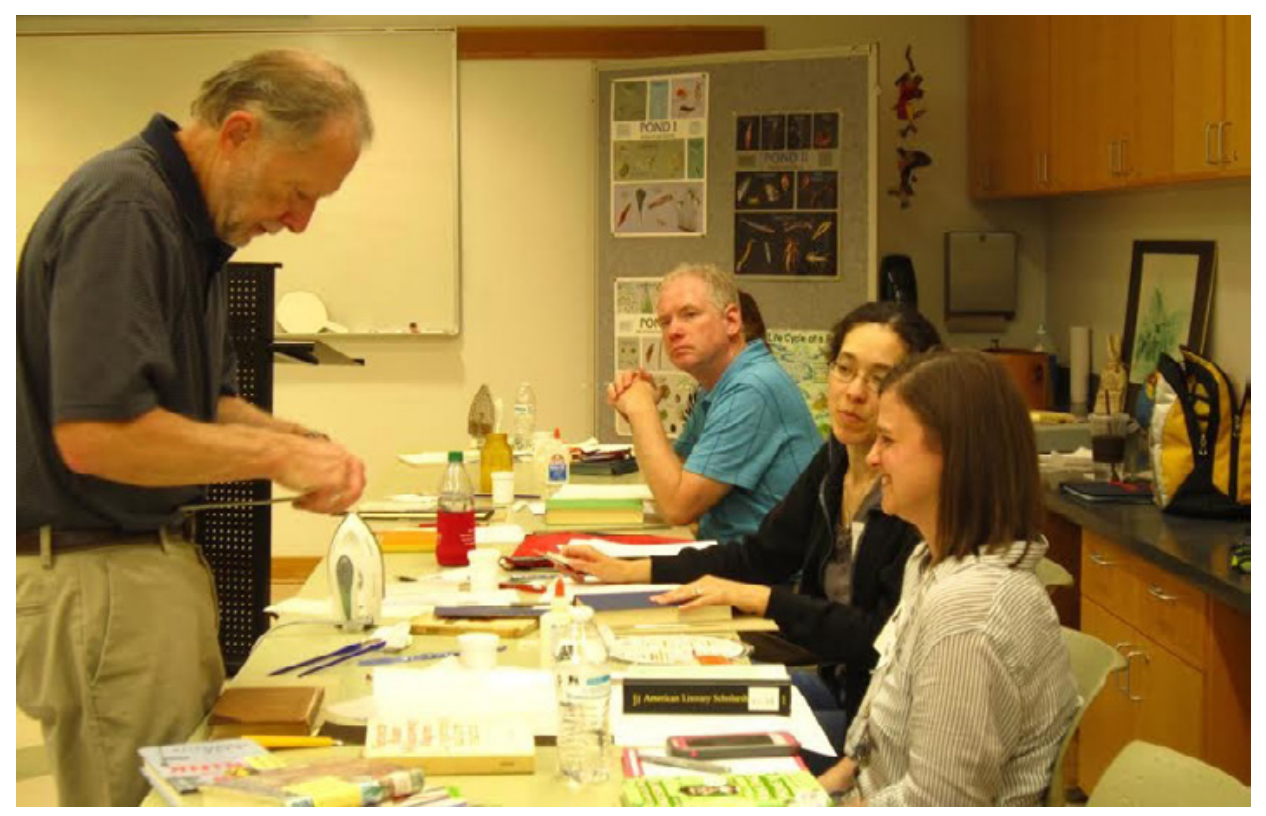

Workshop at Historic Yates Mill Park, Raleigh, NC, June 2016

process creates a strong repair, which makes the book usable again immediately. This repair can be used to strengthen broken joints inside a book, as well as where the cover is separated.

Another simple repair that I teach is using a material called "heat-set tissue." This describes a thin archival tissue with heat-activated adhesive on one side. Heat-set tissue can be used to mend a paper tear very easily or act as backing for fragile items printed on one side such as posters, printed items, or dust jackets. A thin piece of heat-set tissue is torn or cut to extend beyond the tear, covering it fully. After heating up the tissue with a conventional iron or tack iron, it adheres to the page and, because it is translucent, the text can still be read easily.

One of the most useful repairs undertaken in the workshop is spine replacement. When the spine of a book is damaged severely, you can remove the old spine and create a new one that is glued into the book. Of course, this repair is not appropriate for special collections materials or other rare items. However, for circulating materials, spine replacement is ideal for cloth-bound books and, done well, will last a long time. This technique can also be adapted for books with paper or board covers. The replacement process involves removing the damaged spine from the book by cutting through the book cloth and lifting the book cloth from the cover boards enough to insert a new spine piece. This new spine piece is constructed from buckram or book cloth and is glued onto the book board, underneath the lifted book cloth. The repaired book is then placed into a press or dried under a weight. If the old spine piece is still legible, it can be glued onto the new spine piece which preserves the book's original appearance. When the book isn't covered by cloth, the new spine piece can be glued around the book's spine area, covered with wax paper, and then put in a press or under a weight to dry.

Workshops also cover a few other simple repairs that can keep books "on the road," such as tightening loose hinges and repairing damaged corners. To tighten a loose hinge, where the text block is pulling away from the cover boards, place a small amount of PVA along the boards where the end sheet, the paper that holds the text block to the cover, has pulled away. I often use a small brush to paint PVA 


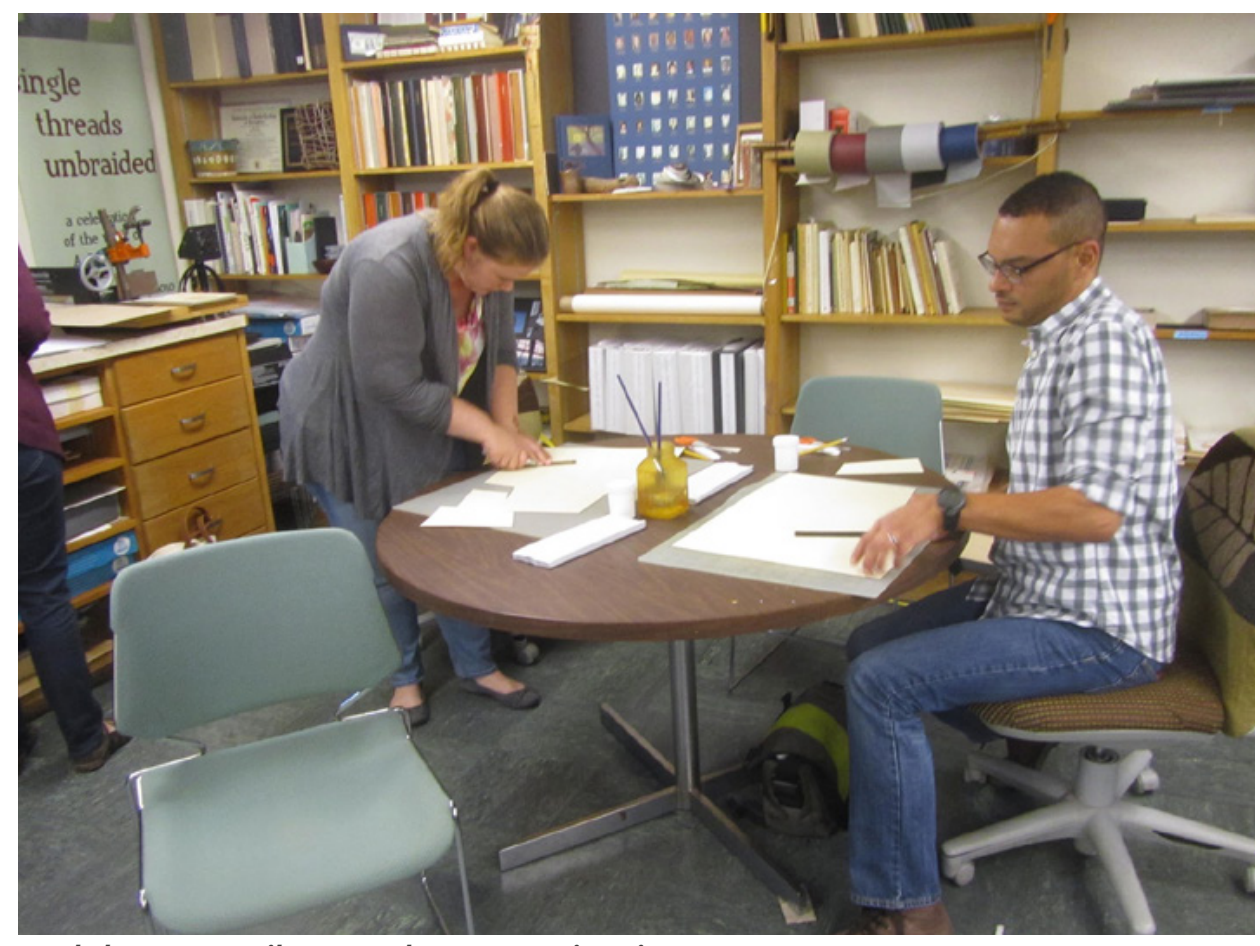

Workshop at ZSR Library, Wake Forest University

inside this loose hinge, but many other methods exist, such as using knitting needles, acrylic rods, or dowels painted with PVA, or the gravity-drip technique. No matter the method, once the PVA is inside both loose hinges, the book is placed to dry under a weight, with wax paper slipped inside the cover if needed.

Corner repair can be tackled several ways. For very damaged corners, the rough edge can sometimes be consolidated by brushing a little PVA into the layers of the board and then pressing it along with wax paper, for protection. To press the corner, use small squares of wax paper and 2-inch squares of binder's board, sandwiched around the damaged book corner; hold it all together with a bullnose clamp. In the case of missing corner pieces, trace out the missing area onto binder's board, cut that out, and then attach to the damaged corner using PVA. When dried, cover it all with book cloth to strengthen the repair. To make that covering process easier, I made a template that I use to trace out the corner repair shape onto book cloth. This template is designed to cover both the exterior and interior of the book corner. After I trace the template shape, I cut it out and glue the cloth onto the repaired corner with PVA. Another corner repair technique is to shave hemp twine into a small ball, add PVA, and use this mix to fill missing corner areas, then press between wax paper and board pieces with a bullnose clamp. It's twinemache!

End sheets, since they must hold the book's text block to two cover boards, are usually a heavier weight paper than the text. They are glued just slightly onto the edge of the text block, about an eighth of an inch. The portion of the end sheet that is glued onto the cover is called the pastedown. There is then the eighth of an inch portion that is glued onto the edge of the text block. The remainder of the end sheet is loose and is called the flyleaf. Specialty end sheet papers may be purchased from most library suppliers. You need to measure and cut the sheet to fit the open book: with the front cover open, measure from the outer left edge of the cover to the outer right edge of the text block to get the length. The height of the sheet will be the text block's height. The end sheet is then glued to the inside of the front cover, and one eighth of an inch is glued onto the left edge of the text block. The book is then placed into a press, with wax paper inside to complete the repair. This repair is a good and simple method to repair broken joints.

A number of preservation and conservation professionals teach book repair workshops across the country. However, many workshops are not affordable, geographically convenient, or offered often enough. In North Carolina, book repair workshops are offered in a variety of locations across the state at different times of the year. For those interested in these opportunities but with no good local option, national organizations such as The Association for Library Collections and Technical Services (ALCTS), Lyrasis, and a variety of private organizations offer training.

If you can find one that suits your constraints, book repair workshops are helpful for library staff with limited budgets who want to extend the life and use of their materials for their users. Attendees who I meet are always excited to learn these techniques and tricks to take home to their institution. The following are my favorite workshop resources.

\section{Print Resources for Book Repair}

Kamph, Jamie. Tricks of the Trade: Confessions of a Bookbinder. New Castle, DE: Oak Knoll, 2015.

Lavender, Kenneth. Book Repair: A How-To Manual. New York: NeilSchuman, 2001.

McQueen, Sharon and James Twomey. In-House Bookbinding and Repair. New York: Rowman and Littlefield, 2015. 
Young, Laura S. Bookbinding \& Conservation by Hand: a working guide. Oak Knoll, 1995.

\section{Online Book \\ Repair Manuals}

Universities with a robust Preservation staff often publish book repair manuals. These are a few excellent examples:

Indiana University Preservation Manual - https://libpres.sitehost. iu.edu/manual/

Dartmouth University Simple Book Repair Manual - https://www. dartmouth.edu//library/preservation/repair/index.html

Alaska State Library Conservation Book Repair - https://library.alaska. gov/hist/conman.htm

\section{Listservs}

Book_Arts-L - https://www.philobiblon.com/book arts-l.shtml Founded June 23, 1994, Book_Arts-L is a mailing list based at Syracuse University, and managed by Peter Verheyen. It currently claims almost 3000 subscribers worldwide, among them practicing bookbinders, book-artists, marblers, papermakers, printers, collectors, curators in libraries.

CoOL (Conservation Online) https://cool.culturalheritage.org/ Conservation OnLine (CoOL) is a freely accessible platform to generate and disseminate vital resources for those working to preserve cultural heritage worldwide.

Library of Congress Preservation https://www.loc.gov/preservation/

Northeast Document Conservation Center - https://www.nedcc.org/
PADG (ALCTS Preservation Ad-

ministrators Interest Group) -

https://lists.ala.org/sympa/arc/padg

\section{Suppliers}

Archival Products

https://archival.com/products.html

Gaylord Archival

https://www.gaylord.com/

Talas

talasonline.com

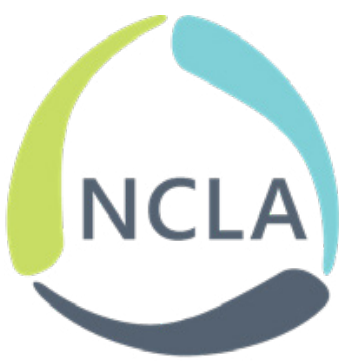

North Carolina Library Association

University Products

https://www.universityproducts. com/

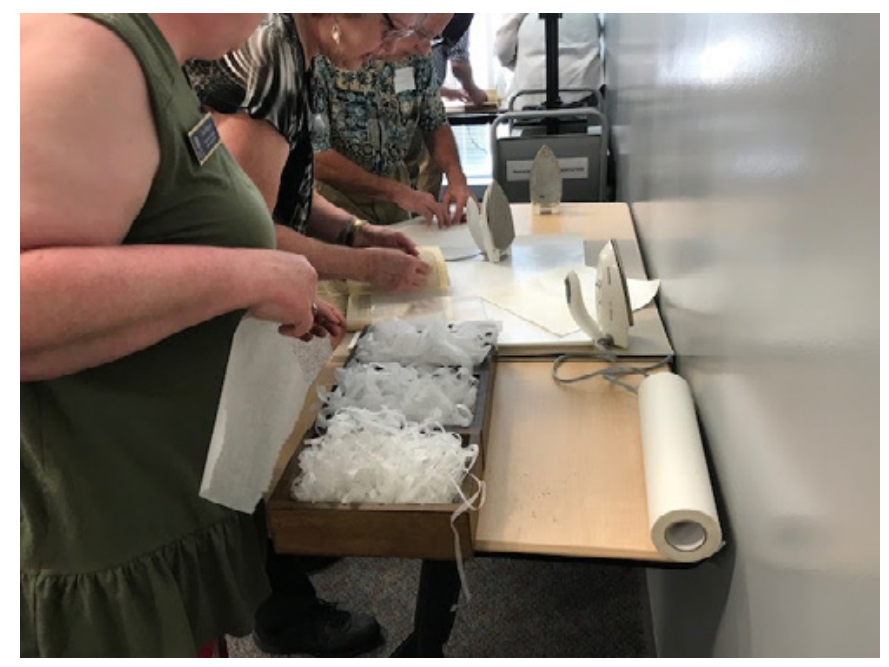

Applying heat-set tissue at East Carolina University, Greenville, NC

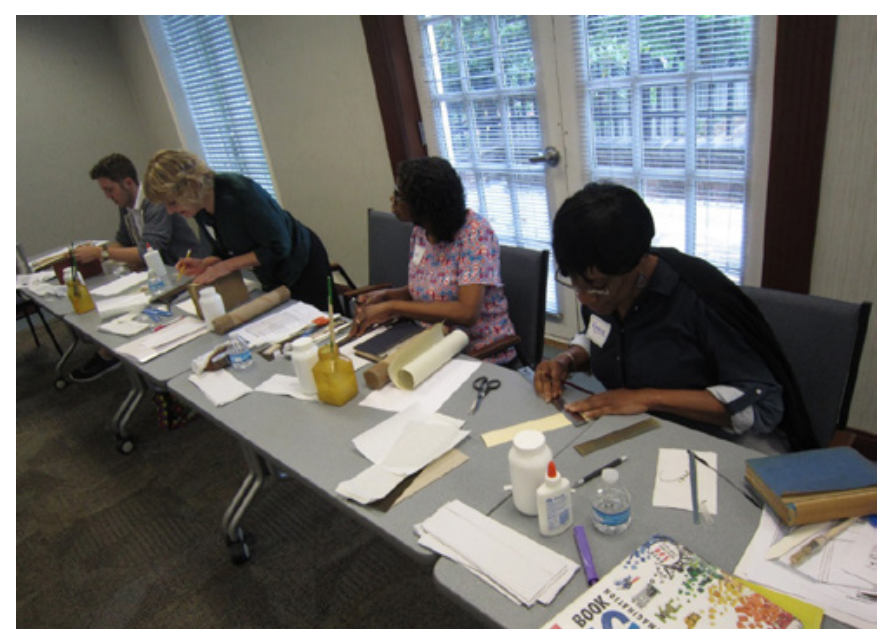

Workshop at Shepard-Pruden Library, Edenton, NC 